\title{
Acute cold stress and mild hypothermia impact on short-term, working memory and attention
}

\author{
Henrikas Paulauskas*, \\ Marius Brazaitis, \\ Dalia Mickevičienè, \\ Kazimieras Pukẻnas,

\section{Nerijus Eimantas} \\ Sports Research \\ and Innovation Institute, \\ Lithuanian Sports University, \\ Sporto St. 6, \\ LT-44221 Kaunas, Lithuania
}

\begin{abstract}
The effect of single acute cold water exposure on the cognitive function (short-term, working memory and attention) was examined in 25 male subjects who were exposed to $14{ }^{\circ} \mathrm{C}$ cold water (air temperature $\sim 22^{\circ} \mathrm{C}, \mathrm{rh} \sim 45 \%$ ) in the semi-recumbent posture (up to the shoulders) until the rectal temperature $\left(\mathrm{T}_{\mathrm{re}}\right)$ dropped to $35.5^{\circ} \mathrm{C}$. 6 subjects were excluded from the study, because we do not reach a necessary condition to drop their $\left(\mathrm{T}_{\mathrm{re}}\right)$ to $35.5^{\circ} \mathrm{C}$ in 170 minutes during a passive cooling procedure. During the cold exposure rectal $\left(\mathrm{T}_{\mathrm{re}}\right)$, skin $\left(\mathrm{T}_{\mathrm{sk}}\right)$ temperatures, heart rate $(\mathrm{HR})$ were measured and cold strain (CSI) was calculated. A cognitive test battery (EFFECTON-COLD) was administrated two times (randomized): as a control measurement (CONTROL) and after the single acute cold water exposure (COLD). After COLD $\mathrm{T}_{\mathrm{re}}$ and $\mathrm{T}_{\text {sk }}$ significantly decreased $(\mathrm{p}<0.05)$. The average of HR and COLD time was $82.61 \pm 4.09$ and $93.68 \pm 8.66$, respectively. The COLD induced CSI resulted as high cold strain $(7.02 \pm 0.22)$. The present study manifested that mild hypothermia and high cold strain experienced in humans during acute cold stress, impair memory and attention tests performance in more complex tasks (tasks requiring working memory, attention concentration, sustention and speed of information processing) while simple tasks remain unaffected (tasks requiring short-term memory and attention concentration for fast response).
\end{abstract}

Key words: acute cold stress, short-term memory, working memory, attention, cognitive function

\section{INTRODUCTION}

Accidental exposure to cold is frequent in Northern countries. The main activities associated with exposure to cold include boating, snowmobiling, other types of land and air transport, non-aquatic activities such as walking, playing, skating, hunting and fishing on ice, and other non-aquatic ac-

\footnotetext{
*Corresponding author. E-mail: paulauskas.h@gmail.com
}

tivities. Also, cold stress may occur for builders, divers, fire-fighters and other workers in everyday occupational activities, especially in winter.

It is well documented that exposure of humans to cold induces physiological changes and may affect cognitive performance (Palinkas, 2001; Lieberman et al., 2009; Muller et al., 2012).

Most of the effects related to cold induce an increment in error numbers and changes in response times in the performance of cognitive 
performance tests assessing attention and memory. Memory tests are used to assess the stages of short-term memory: memorization, storage and recall (Morey, Cowan, 2005), and attention tests allow investigating the main characteristics of attention: stability, concentration, distribution and transfer (Correani, Humphreys, 2011). Pilcher et al. (2002) performed meta-analysis and demonstrated that under cold conditions $\left(\sim 10{ }^{\circ} \mathrm{C}\right)$ reasoning, learning and memory tasks were impaired. Exposure to acute cold stress impairs the performance of short-term or working memory (Thomas et al., 1989; Duncko et al., 2009) and attention (Teichner, 1958; Muller et al., 2012). Baddeley et al. (1975) reported a significant decrement in memory recall but not in recognition; however, other authors have reported a significant decrement in recognition but not in recall (Ellis et al., 1985). Moreover, Duncko et al. (2009) reported that exposure to a predominantly adrenergic stress procedure such as cold pressor stress can be associated with signs of both enhanced and impaired working memory performance. However, it is well known that acute cold stress exposure increases the levels of catecholamine (Srámek et al., 2000; PalmieriSmith et al., 2007) and other stress hormones (Sramek et al., 2000; Pilcher et al., 2002; LaVoy et al., 2011) which impairs cognitive performance (Elzinga et al., 2005; Robinson et al., 2008). Furthermore, very mild decreases in core temperature $\left(\sim 0.5^{\circ} \mathrm{C}\right)$ have little or even stimulatory effects on the immune function (Brenner et al., 1999), but the modest $\left(\sim{ }^{\circ} \mathrm{C}\right)$ decreases in core temperature have depressive effects on the immune function (Costa et al., 2010).

Sandi and Pinelo-Nava (2007) showed that the effect of stress exposure on learning and memory is complex and is determined by the factors such as the length of stress exposure, nature of the stress stimulus, specific cognitive function examined, age and gender. The lack of consistency across studies and reviews has been attributed to a variety of factors including, but not limited to, the cognitive task employed, duration of exposure and method used to induce cold stress (Pilcher et al., 2002; Hancock et al., 2007). For a long time, experts in the field have disagreed about which modality of cooling is the most efficient because many have been effectively employed (Costrini, 1990; Armstrong, Maresh, 1999). Kohagli (1983) concluded that cold-water immersion results in cutaneous vasoconstriction, a paradoxical increase in core temperature with increased heat production at skin temperatures of less than $28^{\circ} \mathrm{C}$, and patient's discomfort. Thus, the body's ability to cool must be stronger than the vasoconstriction that may be evoked by the immersion, and immersion has been found to be the most rapid and effective method of body cooling (Costrini, 1990; Armstrong et al., 1996). Moreover, some investigators used a model in dogs and compared ice-water immersion ( 1 to $\left.3{ }^{\circ} \mathrm{C}\right)$, coldwater immersion $\left(10\right.$ to $\left.11{ }^{\circ} \mathrm{C}\right)$, and tap-water immersion $\left(15\right.$ to $\left.16{ }^{\circ} \mathrm{C}\right)$ and found no significant differences among the 3 immersions (Magazanik et al., 1980).

Most of investigations analyzing cold stress responses to cognitive performance were limited by exposure time (Mäkinen et al., 2006; Lieberman et al., 2009; Muller et al., 2012; Seo et al., 2013), but in a recent study Brazaitis et al. (2014) induced cold stress by body immersion in cold water and examined the physiological responses in two groups of subjects: those who exhibited a fast decrease in rectal temperature $\left(\mathrm{T}_{\mathrm{re}}\right)$ (fast cooling, $\mathrm{FC}$ ) and those who exhibited a slow decrease in $\mathrm{T}_{\mathrm{re}}$ (slow cooling, SC). Accordingly, we assume that cold exposure, limited by time in earlier studies, might induce different responses on $\mathrm{T}_{\mathrm{re}}$ and subject's cognitive function could be affected differently. According to cold stress studies the modest $\left(\sim 1^{\circ} \mathrm{C}\right)$ decreases in core temperature have depressive effects on the immune function (Costa et al., 2010), increases the levels of catecholamine (Srámek et al., 2000; Palmieri-Smith et al., 2007) and other stress hormones (Srámek et al., 2000; Pilcher et al., 2002; LaVoy et al., 2011), thus we hypothesized that the method used in our study (exposure to cold-water limited by 
the set point of $\mathrm{T}_{\mathrm{re}} 35.5^{\circ} \mathrm{C}$ ) should induce high cold stress and manifest cognitive performance on tests involving memory and attention.

\section{MATERIALS AND METHODS}

\section{Subjects}

25 healthy male volunteers participated in the study which was approved by the Human Research Ethics Committee (Kaunas University of Medicine, Protocol No. 101/2011; BE$2-41$, Kaunas, Lithuania). Mean $( \pm S E)$ age, weight, height, body fat and skinfold thickness were $21.18 \pm 0.23 \mathrm{yr} ; 78.26 \pm 1.18 \mathrm{~kg}$; $183.50 \pm 0.86 \mathrm{~cm} ; 15.82 \pm 0.81 \%$; and $10.95 \pm 0.60 \mathrm{~cm}$, respectively. The body mass and body fat of each subject was determined by taking their nude body mass with a body composition analyzer (Tanita, TBF-300, Illinois, USA). Skinfold thickness was estimated from the average of the ten skinfold sites (chin, subscapular, chest, side, suprailium, abdomen, triceps, thigh, knee, and calf sites) (McArdle et al., 1984) using a medical skinfold caliper (Seahan, SH5020, Masan, Korea). 6 subjects were excluded from the study, because we do not reached a necessary condition to drop their $\left(\mathrm{T}_{\mathrm{re}}\right)$ to $35.5^{\circ} \mathrm{C}$ in 170 minutes during a passive cooling procedure.

\section{Cognitive function assessment}

Cognitive function testing was conducted from September to December and from March to June to limit the initial heat and cold acclimation through casual exposure to high or low ambient temperatures. A passive cooling session with cognitive function assessment (COLD) or control cognitive function assessment (CONTROL) were conducted indoors at the same time of the day (7:00 am to $11: 00)$ to avoid the confounding effects of circadian rhythms. The subjects could not take any food at least 12 hours prior to the experiment, but they could drink water when they wanted. The subjects were also instructed not to drink any liquid $60 \mathrm{~min}$ before the arrival to the laboratory. This was done in order to standardize the state of hydration and body mass.
The experiment was carried out at $22 \pm 1{ }^{\circ} \mathrm{C}$ room temperature (mean) and $40 \pm 5 \%$ relative humidity (mean). On arrival to the laboratory, the subjects were weighed in the nude and after light dressing (T-shirt, shorts and socks) were asked to rest in a chair for $30 \mathrm{~min}$. Then on the CONTROL day the subjects were asked to perform cognitive test battery. On the COLD day the rectal $\left(\mathrm{T}_{\mathrm{re}}\right)$ and skin $\left(\mathrm{T}_{\mathrm{sk}}\right)$ temperatures were collected as control measurements (CON) and a passive cooling session started. In the passive cooling session the volunteers were immersed in a water bath at $14 \pm 1{ }^{\circ} \mathrm{C}$ in the semi-recumbent posture (up to the shoulders) until $\mathrm{T}_{\mathrm{re}}$ dropped to $35.5^{\circ} \mathrm{C}$ (necessary condition). During this procedure, $\mathrm{HR}, \mathrm{T}_{\text {re }}$ were measured every $5 \mathrm{~min}$. Within $\sim 3$ min after leaving the bath, the volunteers were wiped away with a towel and the temperature measurements $\mathrm{T}_{\mathrm{re}}, \mathrm{T}_{\text {sk }}(\mathrm{CON} 2)$ were repeated again. After light dressing, the subjects were asked to perform cognitive test battery.

\section{Cognitive test battery}

The programmed cognitive test battery (EFFECTON-COLD) was used for memory and attention performance assessment. All tasks were computer controlled with the information being presented on the screen of a laptop (Hp Compaq 6730b). The test battery was performed approximately in $20 \mathrm{~min}$. It should be noted that Bernecke et al. (2012) verified the used tests reliability.

Memory assessment. Memory tests are used to assess the stages of short-term memory: memorization, storage and recall (Morey, Cowan, 2005). To assess the above-mentioned peculiarities, three standard memory tests were selected (Collie et al., 2003), which helped to assess the volume of spatial memory, as well as the memory of 10 two-digit numbers and recognition of 9 figures.

The volume of spatial memory was assessed using "the test of memorizing the quantity of digits". In a highly cited article the psychologist Miller (1956) suggested that normally adult short-term memory has a forward memory span of approximately seven items plus or minus 
two. The Forward Digit Span Task (Miller, 1956; Diamond, 2013) tests the ability to remember the amount of digits per short time period. This test assesses short-term memory (Diamond, 2013), which can hold a limited amount of information in a very accessible state temporarily (Cowan, 2008). The subjects were instructed to remember 7 digits of consecutive sequence which were displayed for 3 seconds in the middle of the screen. The subjects had then immediately entered memorized digits using a numeric keyboard in the same consecutive sequence as they were presented, working from the beginning to the end of the series. If the digits were identified correctly, then for the next attempt one digit was added to the sequence and, if the error was made, then one digit less was displayed. There were 16 sequences. The mean value of digits displayed was recorded.

During the assessment of memory of twodigit numbers, the participants were given a sequence of two-digit numbers on their screens. They had to memorize 10 two-digit numbers, and after their disappearance (every two-digit number was showed for $2.5 \mathrm{sec}-$ onds), enter them into the empty spaces on the computer in random order. The research included two sequences of 10 numbers. The results of the test depended on the number of correct answers of both attempts (maximum 20). The memory of two-digit numbers test analyses working memory (Macizo, Herrera, 2011).

The forced-choice recognition memory test assesses visual recognition and working memory. This test is subsumed for forced choice recognition memory tests (Roediger, Karpicke, 2006). After looking at 9 visual figures which were displayed for 15 seconds in the middle of the screen, the subjects were required to recall 9 items from 28 figures presented in the study list in any order. The number of a correct sample match was recorded.

Attention assessment. Testing of attention allows investigating the main characteristics of attention: stability, concentration, distribution and transfer (Correani, Humphreys,
2011). The research of the mentioned peculiarities included the following tests: assessment of complex reaction and attention transfer.

The unpredictable task switching test is intended to determine the speed of the choice of correct response in a given situation, when a person needs to choose one of the two possible responses to a stimulus as fast as possible (Kubicki et al., 2012). While accomplishing the test for complex reaction assessment, the research participant had to press the right arrow $(\rightarrow)$ as quickly as possible when an even number appeared on the computer screen, and press the left arrow $(\leftarrow)$ when an odd number appeared. While accomplishing the test, attention was focused on one visual field area. The time span between the emergence of numbers (the span between the last pressing of the button and appearance of the next number) shifted from 0.5 to 3 seconds. The variation in time was necessary that the participant would not know when to expect the next number. The duration of the test was 3 minutes; the result depended on the latent period of the responses (the time between the appearance of a number on the screen and pressing on the arrow), the number of responses and the number of correct answers.

The test for attention transfer was intended for the investigation of attention concentration and sustention as well as the speed of information processing (Martens et al., 2010). The essence of this test was a purposeful transfer of attention from one object to another. The research participant was presented with a matrix of 25 hollow and 24 solid numbers. The participants had to arrange the hollow numbers in the increasing order from 1 to 25 , and solid numbers in the decreasing order from 24 to 1 . Using the computer mouse, the numbers were ordered in the following sequence: 1 a hollow number, 24 - a solid number, 2 - a hollow number, 23 - a solid number, etc. The sum of the hollow and solid numbers should always equal to $25(1+24=25,2+23=25$, etc. $)$. The duration of the test was 5 minutes. The result reflected the speed of the accomplishment of the task, which ranged from 0 to 300 seconds. 


\section{Measurements}

\section{Rectal and skin temperatures}

$\mathrm{T}_{\text {re }}$ and $\mathrm{T}_{\text {sk }}$ were measured before and at the end of passive cooling. $\mathrm{T}_{\mathrm{re}}$ was measured using a thermocouple (Ellab, DM852, Denmark) inserted to a depth of $12 \mathrm{~cm}$ past the anal sphincter as recommended (Proulx et al., 2003). $\mathrm{T}_{\text {sk }}$ was measured at three sites: back, thigh and forearm (Ellab, Skin/Surface probe, Denmark) and the average was calculated using the following formula (Burton, 1935):

$$
\mathrm{T}_{\text {sk }}=0.5_{\text {back }}+0.36_{\text {thigh }}+0.14_{\text {forearm }} \text {. }
$$

\section{Cardiovascular responses}

HR was measured before and every 5 min during passive cooling with a heart rate monitor (Polar 625x, Finland).

\section{Cold strain index (CSI)}

The cold strain index (CSI) was based on $\mathrm{T}_{\mathrm{re}}$ and $T_{\text {sk }}$ as a rating of cold strain on a universal scale of 0-10: 1-2 (no/little cold strain); 3-4 (low cold strain); 5-6 (moderate cold strain); 7-8 (high cold strain); and 9-10 (very high cold strain). It is as follows (Moran et al., 1999):

$$
\begin{aligned}
& \text { CSI }=6.67\left(\mathrm{~T}_{\text {ret }}-\mathrm{T}_{\text {re } 0}\right) \times\left(35-\mathrm{T}_{\text {re } 0}\right)^{-1}+ \\
& +3.33\left(\mathrm{~T}_{\text {skt }}-\mathrm{T}_{\text {sk } 0}\right) \times\left(14-\mathrm{T}_{\text {sk } 0}\right)^{-1} .
\end{aligned}
$$

The measurements for CSI were taken before $\left(\mathrm{T}_{\text {reo }}, \mathrm{T}_{\text {sk } 0}\right)$ and at the end of passive cooling $\left(\mathrm{T}_{\text {ret }}, \mathrm{T}_{\text {skt }}\right)$; water temperature was $14{ }^{\circ} \mathrm{C}$ and $\mathrm{T}_{\text {re }}$ threshold was $35^{\circ} \mathrm{C}$. $\mathrm{T}_{\mathrm{re}}$ and $\mathrm{T}_{\text {sk }}$ were assigned with weight by using a constant of 6.67 and 3.33 , respectively.

\section{Research design}

The research design is presented in Figure. The subjects were required to attend the laboratory on four separate occasions. The initial 2 visits involved familiarization with experimental procedures and equipment. In both familiarization visits the subjects performed all 5 cognitive tests 2 times with a one-hour brake. A week after the familiarization, participants arrived to the laboratory and after a 30-minute

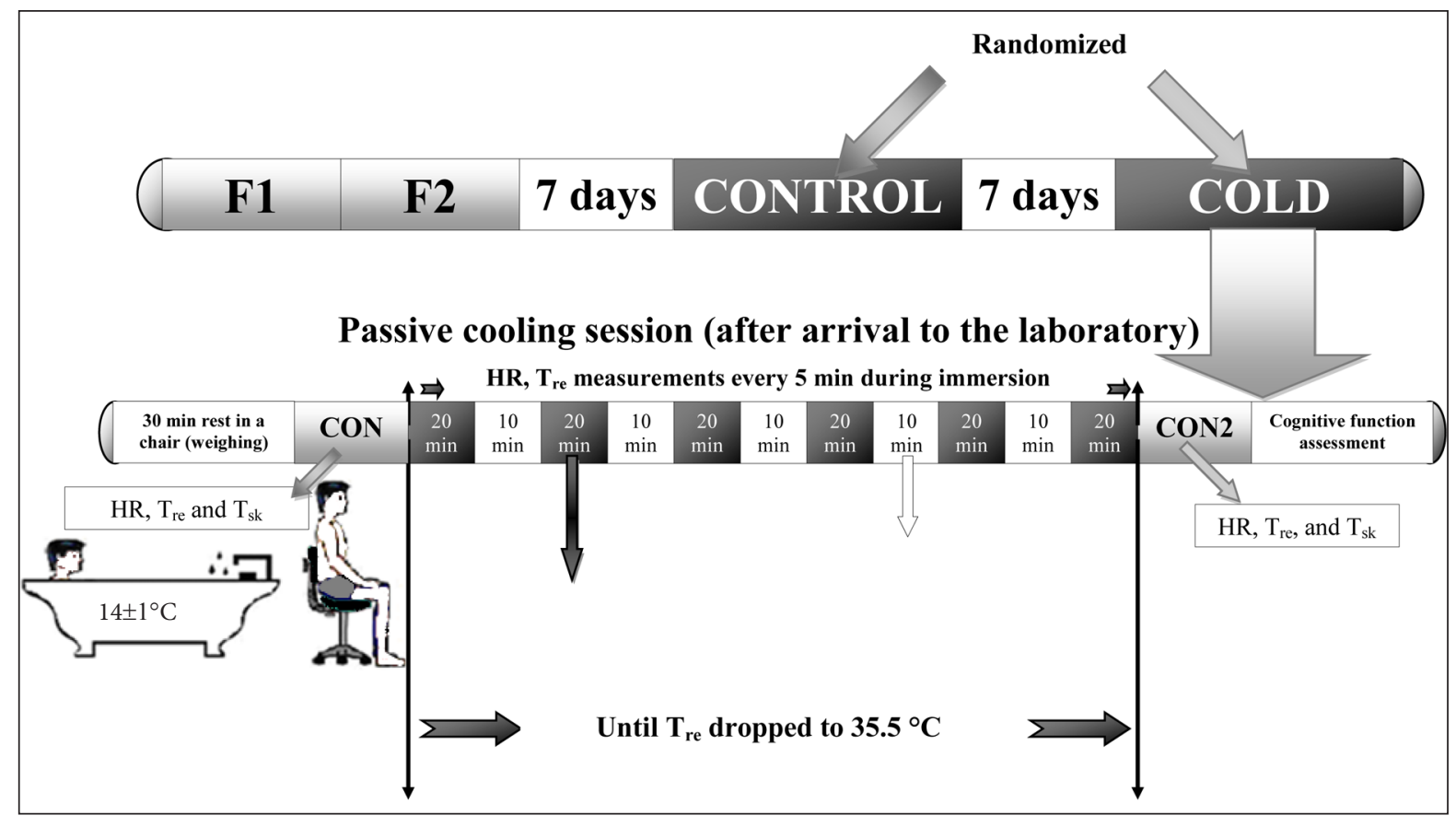

Figure. The research design. Familiarization (F1, F2), 7 days (off days), control cognitive function assessment (CONTROL), cognitive function assessment after passive cooling (COLD), control measurements $(\mathrm{CON}, \mathrm{CON} 2)$ 
rest in a chair the passive cooling session with cognitive function assessment (COLD) or control cognitive function assessment (CONTROL) began. The experimental procedures (CONTROL and COLD) were randomized.

During the passive cooling session the subjects every $20 \mathrm{~min}$ of immersion were asked to step out from the bath and rest in the chair for $10 \mathrm{~min}$ in room environment and then return to the water bath for the next $20 \mathrm{~min}$ of immersion. This up to shoulder immersion procedure in bath water at $14^{\circ} \mathrm{C} \pm 1$ continued until $\mathrm{T}_{\mathrm{re}}$ dropped to $35.5^{\circ} \mathrm{C}$ and the exposure time was recorded. After this procedure the end $\mathrm{T}_{\mathrm{re}}$ and $\mathrm{T}_{\mathrm{sk}}$ were sampled. During immersion and resting the subjects remained in the semi-recumbent posture with their arms folded across their chests and their legs almost straight and together. $\mathrm{HR}$ and $\mathrm{T}_{\mathrm{re}}$ were recorded every 5 min throughout the cooling procedure.

\section{Statistical analysis}

Statistical calculations were conducted using SPSS 17.0 (SPSS Inc., Chicago, IL, USA). To evaluate the data in terms of statistical significance, repeated measures with the General Linear Model (GLM) were applied. The partial eta squared $\left(\eta_{\mathrm{p}}{ }^{2}\right)$ was estimated as a measure of the cold stress effect. The level of significance was chosen as $p<0.05$. If a significant effect was found, the statistical power (\%SP, in percent) was calculated. Pearson correlation coef- ficients ( $r$ ) were used to identify relationships between variables. All data are presented as the mean \pm standard error (SE) of the mean.

\section{RESULTS}

\section{Physiological symptoms of passive cooling}

The effect of the passive cooling session is presented in Table 1. After the passive cooling $\mathrm{T}_{\mathrm{re}}$ and $\mathrm{T}_{\text {sk }}$ significantly decreased $(\mathrm{p}<0.05$, $\% S P$ 100). $\mathrm{T}_{\mathrm{re}}$ measured before and after passive cooling session decreased by $1.54 \pm 0.06{ }^{\circ} \mathrm{C}$ ( $\mathrm{p}<0.05, \%$ SP 100). The average of heart rate and cooling session time was $82.61 \pm 4.09$ and $93.68 \pm 8.66$, respectively. The cooling session induced cold strain (CSI) resulted as high $(7.02 \pm 0.22)$.

\section{Passive cooling effect on cognitive function}

The effect of acute cold stress on memory and attention performance was observed. Descriptive statistics of memory tests are presented in Table 2. The memory test time after the acute exposure to cold did not significantly prolong ( $\mathrm{p}>0.05$ ). After the passive cooling numbers quantity and recognized numbers in the volume of spatial memory test, correct answers in the memory of two-digit numbers test and the recognized figures in the figure recognition test showed significantly lower values $(\mathrm{p}<0.05)$. However, the percent of correct answers significantly decreased only in the memory of two-digit numbers test and figure recognition

Table 1. Effect of passive cooling

\begin{tabular}{|c|c|c|c|c|}
\hline Session time, $\min$ & \multicolumn{2}{|c|}{$93.68 \pm 8.66$} & & \\
\hline Heart rate, $\mathrm{b} / \mathrm{min}$ & \multicolumn{2}{|c|}{$82.61 \pm 4.09$} & & \\
\hline \multirow[t]{2}{*}{ Cold Strain Index (CSI) } & \multicolumn{2}{|c|}{$7.02 \pm 0.22$} & & \\
\hline & $\mathrm{CON}$ & CON2 & $P$ values & $\Delta$ \\
\hline \multicolumn{5}{|c|}{ Temperature measurements, ${ }^{\circ} \mathrm{C}$} \\
\hline $\operatorname{Rectal}\left(\mathrm{T}_{\mathrm{re}}\right)$ & $37.04 \pm 0.06$ & $35.50 \pm 0.00$ & $\mathrm{p}<0.05$ & $1.54 \pm 0.06$ \\
\hline$\eta_{\mathrm{p}}^{2}$ & 0.97 & & & \\
\hline Skin $\left(\mathrm{T}_{\mathrm{sk}}\right)$ & $32.28 \pm 0.14$ & $19.13 \pm 0.40$ & $\mathrm{p}<0.05$ & $11.08 \pm 1.2$ \\
\hline$\eta_{\mathrm{p}}^{2}$ & 0.98 & & & \\
\hline
\end{tabular}


Table 2. Assessment of memory tests

\begin{tabular}{|c|c|c|c|c|}
\hline & \multicolumn{3}{|c|}{ Memory assessment } & \multirow{2}{*}{$\Delta$} \\
\hline & Control & Cold & $P$ values & \\
\hline \multicolumn{5}{|c|}{ Volume of spatial memory } \\
\hline Percent correct, $\%$ & $48.84 \pm 0.78$ & $48.42 \pm 0.97$ & $\mathrm{p}>0.05$ & $-0.42 \pm 1.08$ \\
\hline Numbers quantity & $6.87 \pm 0.16$ & $6.61 \pm 0.13$ & $\mathrm{p}<0.05$ & $-0.26 \pm 0.10$ \\
\hline$\eta_{\mathrm{p}}^{2}$ & 0.26 & & & \\
\hline Recognized numbers & $6.58 \pm 0.17$ & $6.30 \pm 0.16$ & $\mathrm{p}<0.05$ & $-0.28 \pm 0.10$ \\
\hline$\eta_{\mathrm{p}}^{2}$ & 0.31 & & & \\
\hline Test time, $\mathrm{s}$ & $173.47 \pm 6.49$ & $186.21 \pm 8.59$ & $\mathrm{p}>0.05$ & $12.74 \pm 9.37$ \\
\hline \multicolumn{5}{|c|}{ Memory of two-digit numbers } \\
\hline Percent correct, \% & $55.26 \pm 2.95$ & $48.95 \pm 2.90$ & $p<0.05$ & $-6.32 \pm 2.83$ \\
\hline$\eta_{\mathrm{p}}^{2}$ & 0.22 & & & \\
\hline Correct answers & $11.16 \pm 0.56$ & $9.79 \pm 0.58$ & $\mathrm{p}<0.05$ & $-1.37 \pm 0.58$ \\
\hline$\eta_{\mathrm{p}}^{2}$ & 0.23 & & & \\
\hline Test time, $\mathrm{s}$ & $176.47 \pm 10.63$ & $178.26 \pm 12.75$ & $\mathrm{p}>0.05$ & $1.79 \pm 12.14$ \\
\hline \multicolumn{5}{|c|}{ Forced-choice recognition memory } \\
\hline Percent correct, $\%$ & $83.04 \pm 2.46$ & $75.44 \pm 3.24$ & $\mathrm{p}<0.05$ & $-7.60 \pm 3.07$ \\
\hline$\eta_{\mathrm{p}}{ }^{2}$ & 0.25 & & & \\
\hline Recognized figures & $7.47 \pm 0.22$ & $6.79 \pm 0.29$ & $\mathrm{p}<0.05$ & $-0.68 \pm 0.28$ \\
\hline$\eta_{\mathrm{p}}^{2}$ & 0.25 & & & \\
\hline Test time, s & $70.95 \pm 4.03$ & $68.42 \pm 4.74$ & $\mathrm{p}>0.05$ & $-2.53 \pm 6.60$ \\
\hline
\end{tabular}

Values are means \pm SE. Significant difference compared with CONTROL value, $\mathrm{p}<0.05$. $\Delta-$ mean difference between CONTROL and COLD. $\eta_{\mathrm{p}}{ }^{2}-$ partial eta square as a measure of cold stress effect.

test ( $\mathrm{p}<0.05, \%$ SP 56 and $\mathrm{p}<0.05, \%$ SP 65 , respectively), but did not change in the volume of spatial memory test $(\mathrm{p}>0.05)$. Additionally, we found significant correlations between $\mathrm{T}_{\mathrm{re}}$ and the volume of spatial memory test results $(\mathrm{p}<0.05, \mathrm{r}=0.55)$.
The data analysis of attention tests is presented in Table 3. After the acute exposure to cold the time in the attention transfer test and the reaction in the unpredictable task switching test significantly prolonged $(\mathrm{p}<0.05, \% \mathrm{SP} 99$ and $\mathrm{p}<0.05, \% \mathrm{SP} 100$, respectively). Also, $\mathrm{T}_{\mathrm{re}}$

Table 3. Assessment of attention tests

\begin{tabular}{|c|c|c|c|c|}
\hline & \multicolumn{3}{|c|}{ Attention assessment } & \multirow{2}{*}{$\Delta$} \\
\hline & Control & Cold & $P$ values & \\
\hline \multicolumn{5}{|c|}{ Unpredictable task switching } \\
\hline Percent correct & $95.37 \pm 0.79$ & $95.05 \pm 1.22$ & $\mathrm{p}>0.05$ & $-0.32 \pm 0.74$ \\
\hline Number of responses & $43.74 \pm 0.32$ & $42.84 \pm 0.47$ & $\mathrm{p}>0.05$ & $-0.89 \pm 0.45$ \\
\hline Reaction time, ms & $564.69 \pm 9.53$ & $662.98 \pm 21.30$ & $\mathrm{p}<0.05$ & $98.29 \pm 16.36$ \\
\hline$\eta_{\mathrm{p}}^{2}$ & 0.67 & & & \\
\hline \multicolumn{5}{|l|}{ Attention transfer } \\
\hline Percent correct & $95.74 \pm 1.24$ & $91.05 \pm 1.64$ & $\mathrm{p}<0.05$ & $-4.68 \pm 2.08$ \\
\hline$\eta_{\mathrm{p}}^{2}$ & 0.22 & & & \\
\hline Test time, s & $163.68 \pm 6.97$ & $195.68 \pm 10.98$ & $\mathrm{p}<0.05$ & $32.00 \pm 6.88$ \\
\hline$\eta_{\mathrm{p}}^{2}$ & 0.55 & & & \\
\hline
\end{tabular}

Values are means \pm SE. Significant difference compared with CONTROL value, $\mathrm{p}<0.05 . \Delta-$ mean difference between CONTROL and COLD. $\eta_{\mathrm{p}}{ }^{2}$ - partial eta square as a measure of cold stress effect. 
and $\mathrm{T}_{\mathrm{sk}}$ decrement significantly correlated with the prolonged reaction time in the unpredictable task switching test $(\mathrm{p}<0.05, \mathrm{r}=0.58$ and $\mathrm{p}<0.05, \mathrm{r}=0.51$, respectively). After the passive cooling, the number of responses and correct answers in the unpredictable task switching test did not significantly decrease ( $p>0.05$ ). However, the percent of correct answers significantly decreased in the attention transfer test $(\mathrm{p}<0.05, \%$ SP 57).

\section{DISCUSSION}

The present study investigated the effects of single acute cold water exposure on cognitive performance (short-term, working memory and attention). Our raised hypothesis proved and the method used in our study (exposure to cold-water limited by the set point of $\mathrm{T}_{\text {re }}$ $35.5^{\circ} \mathrm{C}$ ) induced high cold stress and manifested cognitive performance impairment in both memory and attention tests.

In our study used passive cooling procedure caused peripheral and central body cooling. The skin temperature manifests the peripheral cooling ratio. In our study $\mathrm{T}_{\text {sk }}$ decreased by $11.08 \pm 1.2{ }^{\circ} \mathrm{C}$, compared with the control conditions. To set the central cooling ratio we chose the set point of $\mathrm{T}_{\mathrm{re}} 35.5^{\circ} \mathrm{C}$. This type of $\mathrm{T}_{\mathrm{re}}$ decrement is described as mild hypothermia (Patel et al., 2012) and may occur in everyday occupational or leisure time activities, especially in winter. O'Brien et al. (2007) studied solders and demonstrated that $\mathrm{T}_{\text {re }}$ decrement by $0.3-1.0{ }^{\circ} \mathrm{C}$ after cold water immersions $\left(10\right.$ and $15^{\circ} \mathrm{C}$ ) can maintain cognitive performance despite mild hypothermia. However, various conclusions exist in previous studies. When humans are exposed to cold conditions which produce modest or no effect on core body temperature $\left(2{ }^{\circ} \mathrm{C}\right.$ or less), improvements, no change, or decrements in various cognitive functions are reported (Pilcher et al., 2002; Hancock et al., 2007). The lack of consistency across studies and reviews has been attributed to a variety of factors including, but not limited to, the cognitive task employed, duration of exposure and method used to induce cold stress (Pilcher et al., 2002; Hancock et al., 2007).

The main difference in our study was limitation by rectal temperature. All subjects dropped $\mathrm{T}_{\mathrm{re}}$ to $35.5{ }^{\circ} \mathrm{C}$ (necessary condition) and the average of $\mathrm{T}_{\mathrm{re}}$ decrement was $1.54 \pm 0.06^{\circ} \mathrm{C}$, which indicates that deep body cooling had initiated. According to cold stress studies the modest $\left(\sim 1{ }^{\circ} \mathrm{C}\right)$ decreases in core temperature have depressive effects on the immune function (Costa et al., 2010), increases the levels of catecholamine (Srámek et al., 2000; Palmieri-Smith et al., 2007) and other stress hormones (Srámek et al., 2000; Pilcher et al., 2002; LaVoy et al., 2011). We did not took the blood samples, but calculated that our used single passive cooling procedure induced a very similar level of cold stress for all subjects (the mean CSI resulted as high as $7.02 \pm 0.22$ ). The similar level of cold stress should induce the comparable changes in blood markers and cognitive performance. According to the Brazaitis et al. (2014) study for the subjects who exhibited the decline in $\mathrm{T}_{\mathrm{re}}$ to $35.5^{\circ} \mathrm{C}$ after the intermittent cold water exposure glucocorticoid cortisol (stress hormone) and catecholamines (ephinephrine, norephinephrine) concentrations were significantly increased. Increase in catecholamines (Arnsten, 1998; Karlamangla et al., 2005) and glucocorticoids (Barseqyan et al., 2010) are associated with decrement in the cognitive function, especially in working-memory.

Mäkinen et al. (2006) showed two distinct explanations existing for the changes in cognitive performance during cold exposure. The negative effects of cold exposure and cold-related physiological changes on cognitive performance are consistent with the distraction hypothesis (Teichner, 1968; Davis et al., 1975) and the positive effects of cold exposure and cold-related physiological changes on cognitive performance are consistent with the arousal hypothesis in which cold exposure results in an initial improvement in performance before it results in a performance decrement (Ellis, 1982; Ellis et al., 1985). Mäkinen et al. (2006) endorsed arousal hypothesis when examining 
the association between $\mathrm{T}_{\mathrm{re}}$ and cognitive performance and presented that with a slight decline in core body temperature (from 37.1 to $36.7{ }^{\circ} \mathrm{C}$ ), participants became more aroused or engaged in performing the task, viewed the cold as a challenge and devoted greater attention to completing all tasks. We discarded this hypothesis because, as we mentioned before, found the impairments in both memory and attention tests. A previous cold water immersion study demonstrated that an initial cooling (not causing a marked drop in $\mathrm{T}_{\mathrm{re}}$ ) improved cognitive performance of complex tasks (Giesbrecht et al., 1993). Eventually, the $\mathrm{T}_{\mathrm{re}}$ temperature dropped further in our study and adverse cognitive performance outcomes have been observed (it consists with the distraction hypothesis). In our experimental study, reaction time, working memory and executive function declined during acute cold exposure. These types of abilities are mediated by frontal brain regions (Tsuchida, Fellows, 2009) and are known to be adversely impacted by cold stress.

Analysing the memory tests results we found a decrement of correct answers percent in all memory tests but test time was not shortened or prolonged significantly and it could be a reason that the main aim in these tests was accuracy. We found a significant impairment of correct answers percent in the memory of two-digit numbers test (working memory) and forced-choice recognition memory test (working memory and visual recognition memory), but the volume of spatial memory test results, which analyse short-term memory (Diamond, 2013), was not significantly impaired. However, the short-term memory test significantly correlated with rectal temperature decrement and it indicates that deeper changes in rectal temperature should be critical on short-term memory. The present study shows that single acute cold stress and mild hypothermia do not affect short-term memory, but affects working memory. Diamond (2013) reported that working memory (holding information in mind and manipulating it) is distinct from short-term memory (just holding information in mind). Additionally, Atkinson and Shiffrin (1971) presented that short-term memory has a maximum duration of about 30 seconds and items can be kept in short-term memory by repeating them verbally (acoustic encoding), a process known as rehearsal. The volume of spatial memory task (short-term memory task) tests the ability to remember the amount of digits per short time period (Miller, 1956; Diamond, 2013) and output has been given immediately after 3 seconds appearance of digits. It is distinct from the memory of twodigit numbers test and forced-choice recognition memory test (memory tests analysing working memory) where output has been given after 25 and 15 seconds, respectively. Peterson and Peterson (1959) showed that the longer the delay, the less information is recalled. According to our results more complex tasks (like tasks analysing working memory) are affected by mild hypothermia after acute cold stress while simple tasks (like tasks analysing short-term memory) remain unaffected. It should be noted that working memory has been found to correlate with intellectual aptitudes (and especially fluid intelligence) better than measures of short-term memory and, in fact, possibly better than measures of any other particular psychological process (Daneman, Carpenter, 1980; Kyllonen, Christal, 1990; Daneman, Merikle, 1996; Engle et al., 1999; Conway et al., 2005). The present study of single acute cold exposure agrees with the few studies that have examined the effects of repeated exposures to cold temperatures which found either no effect of cold exposure or that performance is attenuated in complex cognitive tasks, while simple tasks remain unaffected (Ellis, 1982; Ellis et al., 1985; Enander, 1987; Thomas et al., 1989; Giesbrecht, 1993).

The main aim in attention tests is accuracy and fast response (reaction, i. e. motor response to a visual stimulus). Analysis of attention tests results showed a decrement of correct answers percent in both attention tests, but significant decrement was only in the attention transfer test. The attention transfer test is more complex and requires attention concentration, 
sustention and speed of information processing (Martens et al., 2010), while the unpredictable task switching test requires only attention concentration and fast responses to two possible (odd/even number) stimulus (Kubicki et al., 2012). These findings consist with memory tests results where more complex tasks are significantly affected by mild hypothermia after acute cold stress. The test time in the attention transfer test and the reaction time in the unpredictable task switching test were significantly prolonged. It is a due to significantly lower $\mathrm{T}_{\mathrm{re}}$ and $\mathrm{T}_{\mathrm{sk}}$, we found significant correlations between $\mathrm{T}_{\mathrm{re}}$ and the reaction time and $\mathrm{T}_{\mathrm{sk}}$ and the reaction time in the unpredictable task switching test. Mäkinen et al. (2006) observed that decreased skin temperatures and thermal sensations of cold were associated with longer response times and a decreased efficiency in the simple reaction time task which measures simple visuomotor response times. Also, our data agree with a recent Brazaitis et al. (2014) study, where decrements in the reaction time were observed during the choice reaction task after intermittent immersion in bath water $\left(14^{\circ} \mathrm{C}\right)$.

A series of studies raise the possibility that brain temperatures are somewhat independent from both core and oesophageal temperatures (Harris et al., 2008; Zhu et al., 2009). However, it is unknown how actually temperatures may differ across the brain regions and whether that pattern helps to account for the differential impact of cold exposure on different cognitive abilities. Future neuroimaging studies may help to explain how acute cold stress and mild hypothermia impact the brain function in everyday occupational and/or leisure time activities. Another possibility is that the catecholamine dysregulation associated with acute cold stress and mild hypothermia reduces the cognitive function. Catecholamines are particularly important for tests involving complex attentional functions and executive/ frontal systems functions (Hyafil et al., 2009) which are consistent with the observed pattern of deficits in the current study.

\section{CONCLUSIONS}

In conclusion, the present study manifested that mild hypothermia and high cold strain experienced during acute cold stress impair memory and attention tests performance in more complex tasks (tasks requiring working memory, attention concentration, sustention and speed of information processing) while simple tasks remain unaffected (tasks requiring short-term memory and attention concentration for fast response).

\section{ACKNOWLEDGEMENTS}

The authors acknowledge the subjects who took part in the study.

Received 5 December 2014

Accepted 26 March 2015

\section{References}

1. Armstrong LE, Crago AE, Adams R, Roberts WO, Maresh CM. Whole body cooling of hyperthermic runners: comparison of two field therapies. Am J Emerg Med. 1996; 14: 355-8.

2. Armstrong LE, Maresh CM. Can humans avoid and recover from exertional heatstroke? Adapt Biol Med. 1999; 2: 344-51.

3. Arnsten AF. Catecholamine modulation of prefrontal cortical cognitive function. Trends Cogn Sci. 1998; 2(11): 436-47.

4. Atkinson RC, Shiffrin RM. The control of shortterm memory. Sci Am. 1971; 225(2): 82-90.

5. Baddeley AD, Cuccaro WJ, Egstrom GH, Weltman G, Willis MA. Cognitive efficiency of divers working in cold water. Hum Factors. 1975; 17(5): 446-54.

6. Barsegyan A, Mackenzie SM, Kurose BD, McGaugh JL, Roozendaal B. Glucocorticoids in the prefrontal cortex enhance memory consolidation and impair working memory by a common neural mechanism. Proc Natl Acad Sci. 2010; 107(38): 16655-60. 
7. Berneckè V, Eimantas N, Paulauskas H, Skaisgirytė B, Kudrevičius J, Brazaitis M. Assessment of the reliability of cognitive (attention and memory) tests. Ugdymas. Kūno kultūra. Sportas. 2012; 3(86): 18-25.

8. Brazaitis M, Eimantas N, Daniuseviciute L, Mickeviciene D, Steponaviciute R, Skurvydas A. Two strategies for response to $14{ }^{\circ} \mathrm{C}$ cold-water immersion: Is there a difference in the response of motor, cognitive, immune and stress markers? PLoS One. 2014; 9(10): e109020.

9. Brenner IK, Castellani JW, Gabaree C, Young AJ, Zamecnik J, Shephard RJ, et al. Immune changes in humans during cold exposure: effects of prior heating and exercise. J Appl Physiol. 1999; 87(2): 699-710.

10. Burton AC. Human calorimetry II: the average temperatures of the tissues of the body. J Nutr. 1935; 9: 261-80.

11. Collie A, Maruff P, Makdissi M, McCrory P, McStephen M, Darby D. CogSport: reliability and correlation with conventional cognitive tests used in postconcussion medical evaluations. Clin J Sport Med. 2003; 13(1): 28-32.

12. Conway ARA, Kane MJ, Bunting MF, Hambrick DZ, Wilhelm O, Engle RW. Working memory span tasks: a methodological review and user's guide. Psychon Bull Rev. 2005; 12: 769-86.

13. Correani A, Humphreys GW. An impaired attentional dwell time after parietal and frontal lesions related to impaired selective attention not unilateral neglect. Cogn Neuropsychol. 2011; 28(5): 363-85.

14. Costa RJ, Smith AH, Oliver SJ, Walters R, Maassen N, Bilzon JL, et al. The effects of two nights of sleep deprivation with or without energy restriction on immune indices at rest and in response to cold exposure. Eur J Appl Physiol. 2010; 109(3): 417-28.

15. Costrini A. Emergency treatment of exertional heatstroke and comparison of whole body cooling techniques. Med Sci Sports Exerc. $1990 ; 22: 15-8$.
16. Daneman M, Carpenter PA. Individual differences in working memory and reading. J Verbal Learn Verbal Behav. 1980; 19: 450-66.

17. Daneman M, Merikle PM. Working memory and language comprehension: a meta-analysis. Psychon Bull Rev. 1996; 3: 422-33.

18. Davis FM, Baddeley AD, Hancock TR. Diver performance: the effect of cold. Undersea Biomed Res. 1975; 2: 195-213.

19. Diamond A. Executive functions. Annu Rev Psychol. 2013; 64: 135-68.

20. Duncko R, Johnson L, Merikangas K, Grillon C. Working memory performance after acute exposure to the cold pressor stress in healthy volunteers. Neurobiol Learn Mem. 2009; 91(4): 377-81.

21. Ellis HD, Wilcock SE, Zaman SA. Cold and performance: the effects of information load, analgesics, and the rate of cooling. Aviat Space Environ Med. 1985; 56(3): 233-7.

22. Ellis HD. The effects of cold on the performance of serial choice reaction time and various discrete tasks. Hum Factors. 1982; 24(5): 589-98.

23. Elzinga BM, Roelofs K. Cortisol-induced impairments of working memory require acute sympathetic activation. Behav. Neurosci. 2005; 119: 98-103.

24. Enander A. Effects of moderate cold on performance of psychomotor and cognitive tasks. Ergonomics. 1987; 30(10): 1431-45.

25. Engle RW, Tuholski SW, Laughlin JE, Conway ARA. Working memory, short-term memory, and general fluid intelligence: a latent-variable approach. J Exp Psychol Gen. 1999; 128: 309-31.

26. Giesbrecht GC, Arnett JL, Vela E, Bristow GK. Effect of task complexity on mental performance during immersion hypothermia. Aviat Space Environ Med. 1993; 64: 206-11.

27. Goldman-Rakic PS. Topography of cognition: parallel distributed networks in primate association cortex. Annu Rev Neurosci. 1988; 11: $137-56$. 
28. Hancock PA, Ross JM, Szalma JL. A metaanalysis of performance response under thermal stressors. Hum Factors. 2007; 49: 851-77.

29. Harris BA, Andrews PJ, Marshall I, Robinson TM, Murray GD. Forced convective head cooling device reduces human cross-sectional brain temperature measured by magnetic resonance: a non-randomized healthy volunteer pilot study. Br J Anaesth. 2008; 100: 365-72.

30. Hyafil A, Summerfield C, Koechlin E. Two mechanisms for task switching in the prefrontal cortex. J Neurosci. 2009; 29: 5135-42.

31. Karlamangla AS, Singer BH, Greendale GA, Seeman TE. Increase in epinephrine excretion is associated with cognitive decline in elderly men: MacArthur studies of successful aging. Psychoneuroendocrinology. 2005; 30(5): 45360.

32. Kohagli M. The Makkah body cooling unit. In: Khogali M, Hales JRS, editors. Heatstroke and Temperature Regulation. Sydney, Australia: Academic Press; 1983. p. 139-48.

33. Kubicki A, Bonnetblanc F, Petrement G, Ballay Y, Mourey F. Delayed postural control during selfgenerated perturbations in the frail older adults. Clin Interv Aging. 2012; 7: 65-75.

34. Kyllonen PC, Christal RE. Reasoning ability is (little more than) working-memory capacity? Intelligence. 1990; 14: 389-433.

35. LaVoy EC, McFarlin BK, Simpson RJ. Immune responses to exercising in a cold environment. Wilderness Environ Med. 2011; 22(4): 343-51.

36. Lieberman HR, Castellani JW, Young AJ. Cognitive function and mood during acutecold stress after extended military training and recovery. Aviat Space Environ Med. 2009; 80(7): 629-36.

37. Macizo P, Herrera A. Working memory and two-digit number processing. Memory. 2011; 19(8): 941-55.

38. Magazanik A, Epstein Y, Udassin R, Shapiro Y, Sohar E. Tap water, an efficient method for cooling heatstroke victims - a model in dogs. Aviat Space Environ Med. 1980; 51 (9 Pt 1): 864-7.
39. Mäkinen TM, Lawrence A, Palinkas B, Reeves DL, Pääkkönen T, Rintamäki $\mathrm{H}$, et al. Effect of repeated exposures to cold on cognitive performance in humans. Physiol Behav. 2006; 87(1): 166-76.

40. Martens S, Kandula M, Duncan J. Restricted attentional capacity within but not between sensory modalities: An individual differences approach. PloS ONE. 2010; 5(12): e15280.

41. McArdle WD, Magel JR, Gergley TJ, Spina RJ, Toner MM. Thermal adjustment to cold-water exposure in resting men and women. J Appl Physiol. 1984; 56: 1565-71.

42. Miller GA. The magical number seven, plus or minus two: some limits on our capacity for processing information. Psychol Rev. 1956; 63(2): 81-97.

43. Moran DS, Castellani JW, O'Brien C, Young AJ, Pandolf KB. Evaluating physiological strain during cold exposure using a new cold strain index. Am J Physiol. 1999; 277: R556-64.

44. Morey CC, Cowan N. When do visual and verbal memories conflict? The importance of working-memory load and retrieval. J Exp Psychol Learn Mem Cogn. 2005; 31(4): 70313.

45. Muller MD, Gunstad J, Alosco ML, Miller LA, Updegraff J, Spitznagel MB, et al. Acute cold exposure and cognitive function: evidence for sustained impairment. Ergonomics. 2012; 55(7): 792-8.

46. O’Brien C, Tharion WJ, Sils IV, Castellani JW. Cognitive, psychomotor, and physical performance in cold air after cooling by exercise in cold water. Aviat Space Environ Med. 2007; 78: 568-73.

47. Palinkas LA. Mental and cognitive performances in the cold. Int J Circumpolar Health. 2001; 60(3): 430-9.

48. Palmieri-Smith RM, Leonard-Frye JL, Garrison CJ, Weltman A, Ingersoll CD. Peripheral joint cooling increases spinal reflex excitability and serum norepinephrine. Int J Neurosci. 2007; 117(2): 229-42.

49. Patel JJ, Utting JC, Key ML, Orriss IR, Tay- 
lor SE, Whatling P, et al. Hypothermia inhibits osteoblast differentiation and bone formation but stimulates osteoclastogenesis. Exp Cell Res. 2012; 318(17): 2237-44.

50. Peterson LR, Peterson MJ. Short-term retention of individual verbal items. J Exp Psychol. 1959; 58(3): 193-8.

51. Pilcher JJ, Nadler E, Busch C. Effects of hot and cold temperature exposure on performance: a meta-analytic review. Ergonomics. 2002; 45: 682-98.

52. Proulx C, Ducharme M, Kenny G. Effect of water temperature on cooling efficiency during hyperthermia in humans. J Appl Physiol. 2003; 94(4): 1317-23.

53. Robbins TW, Arnsten AF. The neuropsychopharmacology of fronto-executive function: monoaminergic modulation. Annu Rev Neurosci. 2009; 32: 267-87.

54. Robinson SJ, Sunram-Lea SI, Leach J, OwenLynch PJ. The effects of exposure to an acute naturalistic stressor on working memory, state anxiety and salivary cortisol concentrations. Stress. 2008; 11: 115-24.

55. Roediger HL, Karpicke JD. Test-enhanced learning: taking memory tests improves longterm retention. Psychol Sci. 2006; 17: 249-55.

56. Sandi C, Pinelo-Nava MT. Stress and memory: Behavioral effects and neurobiological mechanisms. Neural Plasticity. 2007; 2007: 1-20.
57. Seo Y, Kim CH, Ryan EJ, Gunstad J, Glickman EL, Muller MD. Cognitive function during lower body water immersion and post-immersion afterdrop. Aviat Space Environ Med. 2013; 84: 921-6.

58. Srámek P, Simecková M, Janský L, Savlíková J, Vybíral S. Human physiological responses to immersion into water of different temperatures. Eur J Appl Physiol. 2000; 81(5): 436-42.

59. Stang PR, Weiner EL. Diver performance in cold water. Hum Factors. 1970; 12(4): 391-99.

60. Teichner WH. Interaction of behavioral and physiological stress reactions. Psychol Rev. 1968; 75: 271-91.

61. Teichner WH. Reaction time in the cold. J Appl Psychol. 1958; 42: 54-9.

62. Thomas JR, Ahlers ST, House JF, Schrot J. Repeated exposure to moderate cold impairs matching-to-sample performance. Aviat Space Environ Med. 1989; 60(11): 1063-7.

63. Tsuchida A, Fellows LK. Lesion evidence that two distinct regions within prefrontal cortex are critical for n-back performance in humans. J Cogn Neurosci. 2009; 21: 2263-75.

64. Zhu M, Ackerman JJ, Yablonskiy DA. Body and brain temperature coupling: the critical role of cerebral blood flow. J Comp Physiol B. 2009; 179: 701-10. 
Henrikas Paulauskas, Marius Brazaitis, Dalia Mickevičienė, Kazimieras Pukènas, Nerijus Eimantas

STIPRAUS ŠALČIO STRESO IR ŠVELNIOS HIPOTERMIJOS POVEIKIS TRUMPALAIKEI, DARBINEI ATMINČIAI IR DĖMESIUI

\section{Santrauka}

Vienkartinis stiprus šalto vandens poveikis kognityvinei funkcijai (trumpalaikei atminčiai, darbinei atminčiai ir demesiui) buvo nustatytas tiriant 25 vyrus. Tiriamieji turejjo gulèti $14{ }^{\circ} \mathrm{C}$ vandens vonioje (oro temperatūra $\sim 22^{\circ} \mathrm{C}$, santykinè oro drègmè $\sim 45 \%)$ panirę iki pečių, kol jų vidinè (rektalinè) temperatūra $\left(\mathrm{T}_{\mathrm{re}}\right)$ pasiekdavo $35,5{ }^{\circ} \mathrm{C} .6$ tiriamųjų duomenys nebuvo ittraukti $\mathfrak{i}$ tyrimo rezultatu analizę, nes nepavyko pasiekti būtinos sąlygos - pasyvaus vėsinimo procedūros metu sumažinti $\left(\mathrm{T}_{\mathrm{re}}\right)$ iki $35,5^{\circ} \mathrm{C}$ per 170 minučių. Vèsinimo metu buvo matuojama vidinè (rektalinè) temperatūra $\left(\mathrm{T}_{\mathrm{re}}\right)$, odos temperatūra $\left(\mathrm{T}_{\text {odos }}\right)$, registruojamas širdies susitraukimų dažnis (ŠSD) ir apskaičiuotas šalčio krūvio indeksas (ŠKI). Kognityvinių testų paketas (EFFECTON-COLD) buvo sprendžiamas du kartus (atsitiktine tvarka): kaip kontrolinis matavimas (KONTROLINIS) ir po vienkartinio stipraus šalto vandens poveikio (ŠALTIS). Po procedūros (ŠALTIS) reikšmingai nukrito $\mathrm{T}_{\mathrm{re}}$ ir $\mathrm{T}_{\text {odos }}(\mathrm{p}<0,05)$. Vidutinis ŠSD buvo $82,61 \pm 4,09 \mathrm{k} / \mathrm{min}$., o vidutinis procedūros (ŠALTIS) laikas 93,68 $\pm 8,66 \mathrm{~min}$. Procedūra (ŠALTIS) sukèlè aukštą ŠKI $(7,02 \pm 0,22)$. Šis tyrimas atskleidè, kad žmonèms, patyrusiems švelnią hipotermiją ir aukštą šalčio krūvị, stipraus šalčio streso metu pablogèja atmintis ir demesys sprendžiant sudètingesnes užduotis (užduotys, reikalaujančios darbinès atminties, dèmesio koncentracijos ir išlaikymo bei informacijos apdorojimo greičio), o paprastesnių užduočių (užduotys, reikalaujančios trumpalaikès atminties ir dèmesio koncentracijos greitam atsakui) sprendimas išlieka nepakitęs.

Raktažodžiai: stiprus šalčio stresas, trumpalaikè atmintis, darbinė atmintis, dèmesys, kognityvinès funkcijos 